\title{
Internet usage in Greek libraries
}

\author{
Eva Semertzaki, Librarian MSc., Bank of Greece, Athens, Greece
}

\author{
Abstract \\ Purpose - The specific goal of this research study is to point out the utilization, integration and \\ exploitation of the Internet among libraries in Greece.
}

Design/methodologylapproach - A survey consisting of 44 questions was distributed to librarians in Greece to collect the data for the study.

Findings - The study reveals that the Internet is an essential and rigorous tool for librarians in Greece. It plays an important role for providing quality and quick reference services to users.

Research limitations/implications - Limitations in this study are related to the small sample size, as well as to the number of variables studied.

Practical implications - The findings of the study would provide some interesting insights into measuring user satisfaction after the introduction of the Internet and into conducting future studies with comparable results.

Originality/value - As far as the author is concerned, there are no similar studies on Greek libraries and Internet. The ICT technologies could have wider implications in all kinds of libraries.

Keywords - Internet, Greece, Greek libraries, user studies, Internet use

Paper type - Research paper

\section{Introduction}

Greece / Hellas is one of the older member states of the European Union (EU) and one of the 12 countries that introduced the Euro in January 2002 . It has a total area of $131,957 \mathrm{~km}^{2}$ and a population of over 11 million. In 2005, the year the country became a Member State of the European Space Agency (ESA), the Gross Domestic Product per capita was $77.3 \%$ of the average of the EU 15 . The growth rate as a percentage of the Gross National Product is predicted to reach 3.9\% in 2007 with a forecast of higher growth to 4\% in 2008 (NSSG, 2007; National Strategic Reference Framework 20072013, 2007).

Compared to membership of the EU and ESA, libraries in Greece have a much longer history. The first known library was organised by the philosopher Aristotle to cover his students' educational needs at his school called Lyceum in the $4^{\text {th }}$ century B.C. Among the prominent libraries in the Hellenistic period were the Alexandria and Pergamon libraries in the $3^{\text {rd }}$ and $2^{\text {nd }}$ centuries B.C. correspondingly. During the Byzantine Empire (330-1453) many libraries operated. In monasteries the monks organised wealthy libraries where they copied handwritten books using papyrus and vellum. In the late $8^{\text {th }}$ and early $9^{\text {th }}$ centuries a shift from parchment to paper occurred. During the Turkish Occupation (14531821) Greek literate people traveled in European countries where they carried important manuscripts to ascertain their safety. In the $15^{\text {th }}$ century with the invention of the typography, Greek publishers opened publishing houses in Vienna, Venice and other European cities. Therefore, they preserved and spread the Hellenic culture and literature (Semertzaki, 2006).

In the $19^{\text {th }}$ century several public libraries operated in Greece. The National Library [1] was inaugurated in 1829 in Egina Island, the first capital of the new independent Greek state. In 1837 when the University of Athens was established, the National Library served as a university library, too. In 1903 the National Library moved to its new building in Athens and separated from the university library. The National Library guarantees the cultural heritage in print and non-print format, but it faces severe housing problems. In 2007 a private foundation signed a memorandum of understanding with the Greek government to build and equip new national library premises by 2013.

\section{Libraries in modern Greece}

During the last 30 years, libraries in Greece gradually began to modernize with academic libraries as the frontrunners. Until recently, however, the structure of the educational system in Greece, particularly in the elementary and secondary education, did not support the use of libraries. In the 1970s high school pupils did not even know what a library was. Afterwards they entered higher educational institutions and had to get accustomed to libraries to accomplish their assignments. However, the big shift to the modern library world was made feasible with the injection of European 
Union funds. The Second (1994-1999) and the Third (2000-2006) Community Support Frameworks contributed extensively to the development, mainly of academic but also of some public libraries. New library buildings were erected, the collections were augmented and new library services to faculties, students and general public were introduced. With the exception of some illuminatory examples, school and special libraries always stay some steps behind their academic counterparts (Papazoglou, 2001).

Libraries in Greece are divided by type of audience and sort of collection. There are:

- academic libraries,

- $\quad$ public (dimossies) libraries, where municipal (dimotikes), children and mobile libraries belong,

- special libraries belonging to various institutions, and

- $\quad$ school libraries, a recent development in Greek libraries (CALIMERA, 2003).

Concerning the education of librarians, there are three library schools of higher education level. Two library schools of the Technological Educational Institutes (TEI) in Athens [2] and Thessaloniki [3] offer four-year programmes. In 1993 the Department of Archival and Library Sciences was established at the Ionian University [4] and has a four-year academic programme. From 2003 it offers postgraduate studies on Information Science, in conjunction with TEl in Athens. Table I provides a description of the libraries and their supervising bodies is provided.

\begin{tabular}{|c|c|c|}
\hline Type of libraries & Number of libraries & Supervising body \\
\hline National Library & 1 & Ministry of Education \\
\hline Academy of Athens [5] & 1 & Ministry of Education \\
\hline Academic: university & $\begin{array}{l}22 \text { (with many branches by } \\
\text { faculty and school) }\end{array}$ & Ministry of Education \\
\hline Academic: TEI & 15 & Ministry of Education \\
\hline Public & 46 & Ministry of Education \\
\hline $\begin{array}{l}\text { Mobile (belong to public } \\
\text { libraries) }\end{array}$ & 26 & Ministry of Education \\
\hline Children & 28 & $\begin{array}{l}\text { Ministry of Education, Centre } \\
\text { of Children and Adolescents }\end{array}$ \\
\hline School & $\begin{array}{l}500+266 \text { in secondary } \\
\text { education (in } 2 \text { phases) }\end{array}$ & Ministry of Education \\
\hline School from 2005 & $\begin{array}{l}25 \text { (a pilot project in primary } \\
\text { education) }\end{array}$ & Ministry of Education \\
\hline Municipal & 450 & Ministry of Education \\
\hline Municipal / city & ca. 400 & $\begin{array}{l}\text { Ministry of Internal Affairs } \\
\text { (local authorities) }\end{array}$ \\
\hline Special & ca. 350 & Individual organisations \\
\hline
\end{tabular}

Table I. Libraries in figures

Source: Greek Ministry of National Education and Religious Affairs

Established in 1980, the National Documentation Centre [6] coordinates plenty of library projects and provides assistance to libraries through the National Network of Scientific and Technical Libraries. It also hosts the Union Catalogue of Serials based on member libraries. It has created and maintains AVEKT, an integrated library system, which is used in many Greek libraries. The National Book Centre [7] coordinates and supports book and reading activities. It makes efforts to disseminate the habit of reading and literacy. Academic, public, children, mobile and some municipal libraries are governed and supported by the Ministry of National Education and Religious Affairs [8]. The Ministry of Internal Affairs administers municipal and city libraries. Their development depends on the city council, but they gradually become valuable source of information for the local authorities.

Academic libraries have made a big progress through the Hellenic Academic Libraries Link (Heal-Link) [9] consortium, established in 1998. Its main purpose is to purchase access to electronic journals of various disciplines and publishers. The consortium was initiated by a team of enthusiastic librarians who wished to save resources and exploit the European Union funds in cost-effective ways for academic institutions (Xenidou-Dervou, 2001). In 2007 the consortium expanded its functions to include a union catalogue of books held by academic libraries. 
Public libraries have also developed a network called Infolibraries [10] under the leadership of the Veria Central Public Library [11], which is a model library and well known for its innovative activities. The library actively participates in European Union projects (e.g. PULMAN, CALIMERA, and MINERVA). Many public libraries, under the leadership of the Livadia Public Library [12], joined forces to create a union catalogue of books held by public and municipal libraries. The utmost aim of the Ministry of Education is to create a national union catalogue.

In some public and municipal libraries a network of 100 Public Information Centres has been launched to provide electronic information services. Some 74 of these Centres are located in existing public and municipal libraries, whereas 26 of them are mobile and operate out of vans as an additional service of mobile libraries. The Greek School Network [13] offers its technical services to connect the mobile libraries to the Internet via the EUTELSAT W3 satellite. The project is co-funded by the Ministry of Education and the Operational Program for the Information Society of the Community Support Framework.

In 1994 the Ministry of Education decided to develop 500 school libraries for secondary education. To that number, 266 new libraries are added. However, they face problems, because some of them operate with school librarians and others with teachers. The Ministry took actions to staff all school libraries with librarians. Furthermore, it initiated a pilot project to establish 25 elementary school libraries. In addition, the Centre of Children and Adolescents govern 28 children libraries and provide cultural activities and educational programmes.

Special libraries belong to private or public organisations, institutions, research centres, enterprises of public sector, hospitals, cultural institutions, banks, monasteries etc. Most of them are subject-oriented; some others are very active in the community they serve and have a high profile in their parent organisation. They cannot be counted effectively, because there is diversity in their legal entity. A team of special librarians has got the initiative to prepare a directory, by approaching as many as they know to fill in a questionnaire with demographic data. The results of this initiative are posted on the Eugenidion Foundation website [14]. Later on, this directory will be hosted on the website of the Association of Greek Librarians and Information Scientists [15], established in 1968.

In 2003 the ex-director of the Goethe Institute library in Athens had the idea of establishing the Organising Committee for the Support of Libraries [16]. It consists of the foreign cultural institutions in Athens (German, French, Italian, US/IRC and Spanish), the National Library, the National Documentation Centre, the National Book Centre, the EU Delegate in Greece, the Association of Greek Librarians and Information Scientists and it remains under the auspices of the Ministry of Education. The Committee is very active in organising conferences, workshops, lectures and other events. It mainly focuses on public and municipal libraries. In 2006 the Committee inaugurated the Synergasia [17], a free online library journal published quarterly in Greek (Doellgast, 2003).

\section{Internet situation in Greece}

The Internet is a network of networks and a predominant means of Information and Communication Technologies (ICT). According to the Internet World Statistics: World Internet Usage and Population Statistics [18], the Internet users in the world are 1,173,109,925 and the Internet penetration rate in the population is $17.8 \%$ (data of June 30,2007 ) compared to the world population of $6,574,666,417$ (2007 estimate). The world usage growth between the years 2000 and 2007 was $225 \%$. Concerning Europe, the Internet penetration as a percentage of the population is $39.8 \%$ and the growth between the years 2000 and 2007 was $206.2 \%$.

The Internet has been available in Greece since the beginning of the 1990s. Since then Internet penetration has seen a remarkable annual growth. According to the abovementioned statistics, the growth between the years 2000 and 2007 was $280 \%$. However, the Internet usage and penetration in Greece (33.5\%) is below the average of the EU 27 countries (51.8\%). Greece proceeds from the phase of "acquaintance" to the phase of "maturity" in terms of the Internet market. In 2004 the Olympic Games in Athens gave a boost to Internet development in the country, because new technologies were implemented and new infrastructure became available. Thus in so far as Greece is concerned the Games became the driving force of leading-edge technologies (Strategic's telecomms, 2002).

During the last decade, ICTs have become widely available and there have been rapid changes associated with the Internet. Many international organisations provide statistics on usage and services 
of ICT; however, data provided by member countries of each organisation (e.g. OECD) may greatly vary, because they have been combined with different data sources to estimate ICT aggregates compatible with national account totals. The major drawback of collecting official statistics is that they are based on different standards and measure rapidly changing behaviour at different points of time (OECD, 2007b). For that reason the selection of statistical data for the purpose of this study are derived from a reliable national source, namely the Observatory for the Greek Information Society [19], which provides accurate and up-to-date figures on Information Society indicators. More specifically the data are based on its study Annual measurement of the eEurope and i2010 indicators, April 2007. The Observatory operates within the framework of the Operational Programme "Information Society" of the $3^{\text {rd }}$ Community Support Framework. The Information Society [20] is a non-profit organisation, which contributes to the ICT policy formulation processes in Greece. It is placed under the supervision of the Ministries of Economy \& Finance and of Interior, Public Administration and Decentralisation. It is cofunded with $75 \%$ by the European Regional Development Fund and with $25 \%$ by national funds.

\section{Internet use in households}

In 2005 more than half of the households in the EU 25 (58\%) had acquired a personal computer. In 2005 one third (32.6\%) of the households in Greece had obtained personal computers. For 2005 the penetration rate of electronic infrastructure into Greek households shows that $39 \%$ of them possessed desktop computers and 11\% laptops. Other types of electronic appliances include television, DVD, mobile phone, electronic games console, Internet access and palmtop computer. Furthermore, in 2006 the corresponding penetration rates were $42 \%$ for personal computers and a considerable increase of $16 \%$ for laptops (Study, 2007b).

Citizens' access to the Internet and its use is the first of the indicators set by EU for the Action plan eEurope and i2010. Regarding the Internet use in Greek households there was an increase of $27.4 \%$ in 2006 compared to $24.2 \%$ in 2005. The Internet use in the EU 25 countries was $51 \%$ in 2006 and $48 \%$ in 2005, though in the EU 15 it was 54\% in 2006 and 53\% in 2005. However, for the period 20052006 a sharp increase occurred in the growth of Internet penetration in Greece (13.2\%), compared to the average of $6.25 \%$ for the EU 25 countries and $1.89 \%$ for the EU 15 (see Table II; Eurostat, 2007; Eurostat, 2005a).

\begin{tabular}{|l|l|l|l|l|l|l|}
\hline $\begin{array}{l}\text { Households with } \\
\text { Internet access }\end{array}$ & $\begin{array}{l}\text { Greece } \\
\mathbf{( \% )}\end{array}$ & $\begin{array}{l}\text { Growth } \\
\mathbf{2 0 0 5 - 2 0 0 6} \\
\mathbf{( \% )}\end{array}$ & $\begin{array}{l}\text { EU 25 } \\
\mathbf{( \% )}\end{array}$ & $\begin{array}{l}\text { Growth } \\
\text { 2005- } \\
\text { 2006(\%) }\end{array}$ & $\begin{array}{l}\text { EU 15 } \\
\mathbf{( \% )}\end{array}$ & $\begin{array}{l}\text { Growth } \\
\text { 2005- } \\
\text { 2006(\%) }\end{array}$ \\
\hline 2005 & 24.20 & & 48.00 & & 53.00 & \\
\hline 2006 & 27.40 & 13.20 & 51.00 & 6.25 & 54.00 & 1.89 \\
\hline Home computers & $\begin{array}{l}\text { Greece } \\
(\%)\end{array}$ & & $\begin{array}{l}\text { EU 25 } \\
\text { (\%) }\end{array}$ & & & \\
\hline 2004 & 29.00 & & 54.00 & & & \\
\hline 2005 & 32.60 & & 58.00 & & & \\
\hline 2006 & 37.60 & & & & & \\
\hline Frequency of use & $\begin{array}{l}\text { Greece } \\
(\%)\end{array}$ & & $\begin{array}{l}\text { EU 25 } \\
\text { (\%) }\end{array}$ & & $\begin{array}{l}\text { EU 15 } \\
(\%)\end{array}$ & \\
\hline 2005 & 17.90 & & 43.00 & & 46.00 & \\
\hline 2006 & 21.70 & & 47.00 & & 49.00 & \\
\hline
\end{tabular}

Table II. Households with Internet access and PCs and frequency of use

Source: Greek Information Society Observatory; Eurostat yearbook 2006-2007; Statistics in focus, Industry trade and services, No. 38 (2005), and; NSSG, 2007.

\section{Internet indicators}

In 2006 the frequency of Internet use in Greece on a weekly basis increased to $21.7 \%$, compared to $17.9 \%$ in 2005. The weekly frequency in the EU 25 was 47\% (2006) and 43\% (2005) and in the EU 15 the corresponding rates were $49 \%$ (2006) and $46 \%$ (2005).

User profiles. The profiles of people that use the Internet at least once a week remain similar to 2005. They are primarily males, of further or higher education. Although an increase is observed in the age group of $35-44$ (from $19.9 \%$ in 2005 to $27.1 \%$ in 2006), it is the age group of $16-24$ that is the most active of all (48.4\%). This is followed by the ages of 25-34 (32.7\%) and ages 35-44 (27.1\%) as shown 
in Table III. What this implies is that the higher the education level, the higher the likelihood of Internet usage.

\begin{tabular}{|l|l|l|}
\hline Age of Internet users in Greece (\%) & $\mathbf{2 0 0 5}$ & $\mathbf{2 0 0 6}$ \\
\hline $16-24$ & 56.6 & 48.4 \\
\hline $25-34$ & 37.3 & 32.7 \\
\hline $35-44$ & 19.9 & 27.1 \\
\hline Place of access in Greece (\%) & $\mathbf{2 0 0 5}$ & $\mathbf{2 0 0 6}$ \\
\hline Home & 72 & 72 \\
\hline Workplace & 39 & 41 \\
\hline Internet cafe & 19 & 13 \\
\hline Libraries & 4 & 1 \\
\hline Reasons for Internet access (\%) & $\mathbf{2 0 0 5}$ & $\mathbf{2 0 0 6}$ \\
\hline Search information for products \& services & 84 & 81 \\
\hline Exchange of e-mails & 70 & 69 \\
\hline Entertainment & 60 & 44 \\
\hline
\end{tabular}

Table III. Age of Internet users, place of access and reasons for using the Internet Source: Observatory for the Greek Information Society.

Location of access. As far as the location of access in Greece is concerned, there is no significant change between 2005 and 2006. Among the major three locations, home is at the top (72\% both in 2005 and 2006, see Table III), followed by the workplace (39\% in 2005 and $41 \%$ in 2006). Other Internet access points are Internet cafés (19\% in 2005 and 13\% in 2006). Regarding the abovementioned indicators, there are no comparable data for the EU. It is important to mention that libraries are included among the places of Internet access but it is worrying that the percentage is very low. Nevertheless, we can assume that because libraries make their websites accessible for public use, Internet users can search them from the primary places of Internet access, e.g. home and workplace.

Reasons for using the Internet. According to the Study of the Greek Observatory (Study, 2007b) the main reasons that Greeks use the Internet in 2006 remain the same as in 2005. The prevailing two reasons are searching information for products and services (81\% in 2006 and $84 \%$ in 2005) and exchanging e-mails (69\% in 2006 and $70 \%$ in 2005). Entertainment is the third reason (44\% in 2006 and $60 \%$ in 2005). Youths (16-24 years) are inclined to use the Internet for playing / downloading games and music with a percentage of $74.2 \%$ in 2004 . At the same time the average of all age groups (16-74) is $55.2 \%$ for Greece (OECD, 2006; OECD, 2005).

Skills of Internet users. According to the study, the Internet users in 2006 asserted that they have never attended a computer training course (46\% in 2006 and 41\% in 2005). Computer and Internet users acquire their skills on their own (54\% in 2005 and 2006), as well as from advice by friends and colleagues (36\% in 2006 and 56\% in 2005) and at school (college or university, 33\% in 2006 and 40\% in 2005). Males mainly state that they have not attended computer training courses in 2006 , while most young respondents reply that they have recently received computer training. Compared to males, more females acquire computer skills at school or from training programmes. Persons of higher education level feel more adequate in using computer and Internet than persons of a lower education level, aged 45-54 (Eurostat, 2006a).

Internet use in Greek enterprises

For consistency reasons we will use the same study Annual measurement of the eEurope and i2010 indicators: Report on the research findings among businesses, April 2007 (Study, 2007a). Concerning the Internet penetration in businesses, Greece reaches the average of the EU 15 and EU 25 countries. Almost all businesses with 10+ staff use computers (99\%). Employees reported that they used computers in enterprises everyday in both 2006 and 2007.

The Internet access in enterprises in 2005 was $92 \%$ in Greece, compared to 91\% in the EU 25 and $92 \%$ in the EU 15 countries. The vast majority of the businesses with over 10 employees have Internet connection (92.5\% in 2006 and 93\% in 2005). The remaining 7.5\% do not have Internet connection because the kind of their activities does not make it necessary. It is particularly significant that all enterprises with over 250 employees have Internet access (100\%) in 2005 and 2006. Compared to the 
EU 25 countries, 93\% of all businesses 10+ have Internet access in 2006 and $91 \%$ in 2005. The rates for the EU 15 countries are 94\% for 2006 and 92\% for 2005 (Eurostat, 2005b; Eurostat, 2006b; Eurostat, 2006c).

The main reasons for using the Internet are for finding information on products and services, for banking and financial services and for monitoring the market. In contrary to the households and individuals, the use of the Internet for transactions with Public Sector Services is widespread among enterprises and specifically large businesses. It is used for finding information, obtaining official forms and submitting filled-in forms.

In Greece the percentage of businesses with over 10 employees that have a website is $56 \%$ for both 2005 and 2006. For the EU 25 countries the rates are 64\% in 2006 and 62\% in 2005. For the EU 15 countries the rates are 65\% in 2006 and $63 \%$ in 2005. It should be highlighted that Greece is approaching the average for EU 25 and EU 15. As the level of training and computer skills of employees are concerned, only $7 \%$ of all businesses report difficulties in finding staff with basic computer skills.

\section{Broadband connections}

In recent years broadband technologies have enjoyed a rapid evolution, because they offer users the ability to transfer large volumes of data in a short period of time and to keep their access lines continuously open. Particularly important is the use of broadband connections (see Table IV). Although in December 2000 Greece accounted for only 72 broadband connections, by December 2005 it accounted for 156,340. It is very positive sign that the average number of monthly broadband connections was 45,470 during the first semester of 2007. On a daily basis (five working days per week) more than 2,066 new broadband connections are implemented. As of $1^{\text {st }}$ July 2007 it was estimated that the total number of broadband connections in Greece amounted 760,698 with a growth of $156.39 \%$ compared to July 2006 (Fifth six-month report, 2007).

\begin{tabular}{|l|l|l|l|l|l|}
\hline $\begin{array}{l}\text { Broadband } \\
\text { connections }\end{array}$ & Greece & $\begin{array}{l}\text { Growth in } \\
\text { Greece 2000- } \\
\text { 2005 (\%) }\end{array}$ & $\begin{array}{l}\text { Penetration in } \\
\text { Greece (\%) }\end{array}$ & $\begin{array}{l}\text { Growth in } \\
\text { OECD 2000- } \\
\text { 2005 (\%) }\end{array}$ & $\begin{array}{l}\text { Penetration in } \\
\text { OECD (\%) }\end{array}$ \\
\hline 2000 & 72 & 364.90 & & 62.30 & \\
\hline 2005 & 156,340 & & 1.50 & & 13.50 \\
\hline June 2006 & & & 2.70 & & 15.30 \\
\hline Jan. 2007 & & & 4.39 & & \\
\hline July 1, 2007 & 760,698 & $\begin{array}{l}\text { 156.39 } \\
\text { (July 2006 - } \\
\text { July 2007) }\end{array}$ & 6.84 & & \\
\hline
\end{tabular}

Table IV. Broadband connections in Greece and in OECD countries

Sources: OECD Communications outlook, 2007 and "Fifth six-month report on broadband development in Greece", July 2007.

In June 2006 the broadband access per 100 inhabitants (broadband penetration) was $2.7 \%$ in Greece (in 2006 it was $4.39 \%$ ), ranked last among the 30 OECD countries, where the total was $15.3 \%$. In 2005 it was $1.5 \%$ and in the OECD countries it was $13.5 \%$. In Greek enterprises with over 10 employees the broadband connection rate was 60\% in 2006 compared to 36\% in 2005. In 2006 the percentage in the EU 25 was $74 \%$ compared to $63 \%$ in 2005. Concerning the EU 15 countries the rate was $77 \%$ in 2006 , whereas in 2005 it was $65 \%$.

According to the findings of the "Fifth six-month report on broadband development in Greece, July 2007" conducted by the Observatory for the Greek Information Society, the broadband penetration in Greece is $6.84 \%$ per 100 inhabitants. The target of $7 \%$ that was set in the $4^{\text {th }}$ semiannual report on broadband penetration in January 2007 has been achieved by July $1^{\text {st }}, 2007$.

Between 2000 and 2005 Greece experienced the highest growth (364.9\%) in broadband connections among the 30 OECD countries, where the growth rate was a mere $62.3 \%$. One reason for the sharp and rapid growth in Greece is related to diminishing the average acquisition cost of equipment. The competition of prices and the high nominal speed of access among broadband providers are the driving forces for the decrease in prices for subscribers' benefit. The domestic retail prices for 
broadband connections are intensively converged to the EU 15. In Greece the prospects for further development of broadband connections, the improvement of services and the shrinking of prices are very promising (OECD, 2007a; Digital Strategy, 2007).

\section{Internet usage in Greek libraries}

Survey studies on the use of the Internet in Greek libraries are scarce, if they even exist. The author herself conducted the present study without any funding from external sources. Several respondents requested feedback and showed their interest in being informed about the results.

\section{Aims and objectives}

The specific goal of this research study is to point out the utilization and exploitation of the Internet among Greek libraries. It aims to declare the degree of embracing new technologies and their implementation in libraries via web services. Its purpose is to illustrate that Internet penetration assists libraries in their endeavours to improve their services to clients, because satisfaction of library users is the ultimate goal of each library.

\section{Methodology}

A survey was conducted to collect the data. A questionnaire was sent to libraries of all kinds around the country. A mailing list hosted by a librarian at the National Documentation Centre (NDC) was the vehicle for the distribution of the questionnaire. A cover note in the form of an e-mail message accompanied a Word file consisting of an introductory letter to explain the reason of circulating the attached survey. It was clearly affirmed that personal data would be kept confidential and the answers would be used only for the purpose of the study. The survey was released on November 29, 2006 and the deadline for submitting the replies was 15 December 2006. However, given the short time for submitting answers and that Christmas holidays were approaching, a reminder was sent again on 10 January 2007 setting as final deadline the 31 January, 2007.

The population of the study is librarians of all kinds of libraries in Greece who are included in the NDC mailing list. It is interesting to remark that only one staff member replied from each library, with very few exceptions. A total of 87 replies were received by e-mail, fax or post. It is estimated, though, that about 20 replies were lost because of bad connections in fax lines. Some questionnaires were also excluded as incomplete and there were no details of the sender to enable further contacts. Although this sample is relatively small, the response rate is rather satisfactory, because it does represents libraries of various kinds.

\section{The questionnaire}

The questionnaire used for this study was designed by the author. It was developed after an extensive literature review, specifically from similar studies on the Internet usage in various sectors and countries. Upon thoroughly checking the literature, the author prepared a list of 44 questions divided into the following four sections with a caption on top of each:

- demographic profile of the library and the librarian,

- information about Internet availability,

- Internet usage,

- consequences of the use of Internet.

The types of questions used were close-ended and in some of them a scale was used (1: worse to 5: best). The data were analyzed using MS Excel.

\section{Findings and discussion}

Age. The majority of the respondents (82.95\%) are female. It is evident that library and information science - in Greece at any rate - is a women's realm. The librarians' age is shown in Table V. The majority of the respondents belong to the "production ages" $25-45$ years with $81.61 \%$. This indicator is important because young people work at libraries and their generation is more acquainted with new technologies and Internet.

\begin{tabular}{|l|l|l|}
\hline Librarians' age & Respondents & Percentage \\
\hline $25-35$ & 33 & 37.93 \\
\hline $36-45$ & 38 & 43.68 \\
\hline $46-55$ & 15 & 17.24 \\
\hline $56-$ & 1 & 1.15 \\
\hline
\end{tabular}


Table V. Librarians' age

Education. As concerns librarians' education per gender (Figure 1), it is worth mentioning that most librarians responding to the survey are graduates from the Library Schools of the Technological Educational Institutes (43 persons: 37 female and 6 male). Librarians holding a master's degree in Library Science include 19 females and 5 males. The number of librarians with postgraduate degrees has increased in recent years compared to 15-20 years ago when there were a limited number of librarians holding master's degrees.

\section{Take in Figure 1}

Types of libraries. Almost all kinds of libraries are represented in this survey. The only kind that is under-represented is school libraries because they are not well developed yet in Greece. Table VI shows that the majority of the respondents (50.56\%) emanate from special / research libraries with 44 responses, followed by academic libraries (21.84\%) with 19 responses. In most cases the positions the respondents hold are low or middle management. The survey revealed that 39 respondents $(45.34 \%)$ were in low positions within the library hierarchy, while 27 (31.03\%) were in middle management.

\begin{tabular}{|l|l|l|}
\hline Types of libraries & Respondents & Percentage \\
\hline Academic & 19 & 21.84 \\
\hline Archive & 1 & 1.15 \\
\hline Public & 10 & 11.50 \\
\hline Public/municipal & 12 & 13.80 \\
\hline Research/special & 44 & 50.56 \\
\hline School & 1 & 1.15 \\
\hline
\end{tabular}

Table VI. Types of libraries

\section{Internet availability}

The second series of questions concern the existence of the Internet in Greek libraries. The questions refer to Internet availability, type of Internet connection, number of computers connected to the Internet, availability of Internet to library users, library website, dependency on parent organisation's website, information contained in it, and parts of the website most heavily used.

The great majority of libraries have Internet access (96.55\%). In fact, only three responding libraries do not have Internet access - for reasons that they are new or small libraries - but they plan to establish a connection. Two thirds of the libraries (57 out of 87 in the sample, 65.52\%) reply that they provide Internet access to their users.

Figure 2 illustrates the type of Internet connection that libraries use for accessing the web (i.e. dial-up I ISDN, net node, wireless, broadband, other). The results point up the high rate of net node connection (33 libraries) in networks (i.e. Hellenic Academic Libraries Link [9] and Greek School Network [13]). Surprisingly, 29 libraries (33.3\%) access the Internet via broadband connections. This percentage is about five times greater than the broadband penetration (6.84\%) in Greece as of $1^{\text {st }}$ July 2007. It is encouraging that Greek libraries have the infrastructure to provide fast Internet, to embrace and implement new technologies.

\section{Take in Figure 2}

\section{Library websites}

With a yes/no question, libraries were asked about the availability of a website. Only the three libraries with no Internet access do not have a website. Library websites are either autonomous (23 replies, 26.44\%) with their own URL address or under the parent organisation's website (38 replies, 43.68\%) or other (5 replies, $5.75 \%$ ). The average year of creating the library website was 2001 . In some cases, libraries noted that they had redesigned their website since its initial creation. This mainly happened in academic libraries that are pioneers in that domain. 
As for contents of library websites, they contain several pieces of information: general information about the library and its services, access to the OPAC and the electronic material, especially electronic journals and access to content such as digital material, books, photos, maps, architectural drawings and musical recordings.

Most libraries use the website for providing general information about their collections and library services (Figure 3). Many libraries include all categories of content specified in the question, while others offer access to material, such as databases. Unexpectedly, electronic journals do not count for much. However, it seems that this part of the website is included in the "all of the above" answer. An interesting conclusion to be drawn is that many libraries use an automated library system for their services, which means that they have converted the card catalogue to online and made it freely available over the Internet. The OPAC is the part of the website with most hits. It is obvious because all users can remotely search a library's catalogue but only internal users are authorised to access electronic materials, such as databases or electronic journals.

\section{Take in Figure 3}

\section{Usage of the Internet}

The third set of ten questions is related to the use of the Internet in libraries. They refer to the e-mail availability, frequency of using e-mail for work purposes, reasons for using Internet, frequency of using the Internet at work, experience in searching the web, problems encountered when using the Internet, necessity for further training in learning how to use the Internet, ways of training expectations and the overall degree of satisfaction from using the Internet.

\section{E-mail availability}

All but three libraries have an e-mail address. The majority of the libraries (65 respondents or $74.71 \%$ ) employ an e-mail address via their parent organisation's mail-server. Concerning the frequency of email use for work reasons, the great majority (88.5\%) exploit it daily. It is apparent that this common communication tool is entirely integrated in librarians' profession.

\section{Reasons for using the Internet}

The reasons of libraries for using the Internet are depicted in Figure 4. The question includes possible reasons to choose from and the respondents could make more than one selections. The breakdown of the findings indicates that downloading material and document delivery are of equal importance (20\%). Using the Internet for answering reference questions counts for $19 \%$. We can conclude that libraries make use of the Internet mainly for reference services and for searching activities on behalf of library users. Therefore, the Internet has become a powerful ready-reference tool. Furthermore, Greek librarians are not much familiarized with new communication and reference tools, such as newsgroups and blogs. The heavy use of the Internet in librarians' daily work is illustrated in the large percentage $(90.8 \%)$ of the replies to the question about the frequency of Internet use, which is used more than once per day.

\section{Take in Figure 4}

\section{Experience and training in Internet use}

Most librarians reply that they have gained experience (48.28\%) and much experience $(29.89 \%)$ from using the Internet. The ways of becoming Internet literate are described in Table VIII in descending order. The respondents could choose more than one answers. Most of them (75.9\%) are selfeducated. The findings comply with librarians' answer that they are experienced in using the Internet. The in-house training is second in range (30 replies, $34.5 \%$ ). We can assume that parent organisations have understood the value to award their employees with computer skills, through continuous education programmes.

\begin{tabular}{|l|l|l|}
\hline Obtaining Internet skills & Respondents & Percentage \\
\hline Self-educated & 66 & 75.9 \\
\hline In-house training & 30 & 34.5 \\
\hline Books about Internet & 22 & 25.3 \\
\hline Other & 12 & 14.0 \\
\hline Colleagues & 9 & 10.3 \\
\hline Friends & 8 & 9.2 \\
\hline
\end{tabular}


Table VIII. Ways of acquiring Internet skills

Although experienced and trained, the respondents replied that they felt they required more training (73.6\%). The approaches for further training to enable librarians to feel self-confident in using the Internet are presented in Table IX The majority prefer in-house seminars (49.4\%). However, library staff are keen to attend seminars organised by library-related bodies, such as the Association of Greek Librarians and Information Scientists (43.7\%), which should play a vital role as educator and organiser of seminars.

\begin{tabular}{|l|l|l|}
\hline Further Internet training & Respondents & Percentage \\
\hline In-house seminars & 44 & 49.4 \\
\hline $\begin{array}{l}\text { Seminars from library related } \\
\text { organisations }\end{array}$ & 38 & 43.7 \\
\hline Handbooks & 2 & 2.3 \\
\hline Other & 1 & 1.1 \\
\hline
\end{tabular}

Table IX. Methods for further Internet training

\section{Problems from Internet use}

It is optimistic that a great percentage of the respondents $(28.7 \%)$ do not face any problems as described in Table $X$. This is consistent with the outcome that librarians are experienced and satisfied with Internet use. Conversely, some others feel that they have not gained sufficient knowledge (27.9\%). The percentage of problems due to slow access speed (27.6\%) and low computer capacity $(10.3 \%)$ cannot be neglected. It presumes obstacles in accessing the Internet. Telecommunication costs is not a barrier any more (4.6\%). This result is coherent with the progress achieved in broadband penetration and the competition between Internet providers in Greece that cause diminishing of connection costs for the benefit of customers, as described in the part of the Internet situation in Greece, earlier in this paper.

\begin{tabular}{|l|l|l|}
\hline Problems encountered & Respondents & Percentage \\
\hline None & 25 & 28.7 \\
\hline Insufficient education & 24 & 27.9 \\
\hline Slow access speed & 24 & 27.6 \\
\hline Low computer capacity & 9 & 10.3 \\
\hline $\begin{array}{l}\text { Incompetent Internet } \\
\text { connections }\end{array}$ & 7 & 8.0 \\
\hline Telecommunication costs & 4 & 4.6 \\
\hline
\end{tabular}

Table X. Problems from using the Internet

The concluding question in this set is connected with the overall opinion of Internet use on a scale of five degrees of satisfaction ( $1=$ "not satisfied at all" to $5=$ "very satisfied"). The average of 3.96 indicates that respondents are very satisfied with using the Internet.

\section{Consequences of the use of Internet}

The last group of seven questions deals with networking of libraries and the degree that Internet influences library policies. The findings reveal that many Greek libraries participate in national networks or consortia. They are members of the Hellenic Academic Libraries Link consortium (HealLink), the National Network of Scientific and Technical Libraries (EDETB) hosted by the National Documentation Centre or the Union Catalog of Public Libraries.

\section{Effect of Internet in library policies}

The questionnaire asked librarians if the Internet affects traditional library services by means of substituting, replacing or supplementing them. With a few exceptions all libraries replied that the Internet supplements library services (95.4\%) - in fact, it is used for improving library services. So the Internet is a blessing, not a threat and positively influences libraries. Some questions asked about the consequences of the Internet in the organisational structure of the libraries. Two thirds of the respondents (63.2\%) replied that they have prepared library policies concerning Internet use. This is 
an indication that the Internet is recognized as a valid and useful tool that is incorporated in library administration.

The administrative effects of the Internet are evidenced in the questions about the cost of Internet services. Regarding consequences on library budget, about half of the respondents (49.4\%) replied negatively. On the other hand, $46 \%$ admit that consequences exist. The next question sought to specify the budgetary effects that are displayed in Table XI. In general, librarians thought that Internet services have no effects on library budgets. Respondents with positive replies, explained that the allocation of expenses is related to Internet services. Access to the electronic resources is predominant (34.5\%). Then costs on electronic journal subscriptions (25.3\%) follow, although this can be counted in the electronic resources costs. As mentioned before, many academic and public libraries are members of consortia and networks. This leads to an additional cost of $11.5 \%$.

\begin{tabular}{|l|l|l|}
\hline Effects on library budget & Respondents & Percentage \\
\hline Cost of Internet services & & \\
\hline Yes & 40 & 46.0 \\
\hline No & 43 & 49.4 \\
\hline N/A & 4 & 4.6 \\
\hline $\begin{array}{l}\text { Allocation of costs for } \\
\text { Internet services }\end{array}$ & & \\
\hline Access to e-resources & 30 & 34.5 \\
\hline e-journal subscriptions & 22 & 25.3 \\
\hline Consortia fees & 10 & 11.5 \\
\hline Other & 4 & 4.6 \\
\hline Total & 66 & \\
\hline
\end{tabular}

Table XI. Effects on Internet services on library budget

Impact on print journal subscriptions.

The last question discloses the deviation from print to electronic material in libraries. It mainly refers to journal subscriptions as displayed in Table XII. The population that answered the question on cost effects (66), replied to the one about the shift from print to electronic. Less than a third (28.7\%) have cancelled print subscriptions as a result of the introduction of electronic journals. It is important to see that a percentage of $37.9 \%$ of libraries have not altered the status of print journals. The conclusion drawn is that Greek libraries still hesitate to proceed to radical changes in their print subscriptions, although many have embraced the new trend of electronic journals.

\begin{tabular}{|l|l|l|}
\hline Print journal subscriptions & Respondents & Percentage \\
\hline Cancellations & 25 & 28.7 \\
\hline Increase of number & 0 & \\
\hline No impact & 33 & 37.9 \\
\hline Other & 8 & 9.2 \\
\hline Total & 66 & \\
\hline
\end{tabular}

Table XII. Effects of Internet on print journal subscriptions

\section{Assessment of findings}

This study was conducted as an attempt to reveal the degree of Internet penetration and integration of Internet services in Greek libraries. It is a representative sample from all kinds of libraries. In the overall analysis of the available data, it is evident that Internet is a blessing and a close companion tool that enhances and enriches services in Greek libraries. The findings provide some interesting insights into demonstrating that young females, graduates of the Library Schools of the Technological Educational Institutes, work in libraries. The increasing number of Internet connections in libraries indicates that the Internet is a necessity for communication reasons (such as e-mail) but also for providing quality and quick reference services to users.

There are disparities among libraries, especially special libraries as regards the speed and ways of Internet connection. Academic institutions are more progressive as closely related to research, than special or public libraries. It seems that although connected to the Internet, special libraries lack the opportunity to network, because they belong to parent institutions with different levels of development. 
It is a hopeful sign that broadband connections have been taken up at such a rapid pace. The results are consistent with the growth of broadband connection in Greece - though at a higher rate $(33.3 \%)$ than the current average (6.84\%). Librarians use the Internet and the e-mail on a daily basis. It proves the importance of those tools for communication and reference reasons. It is also interesting that the majority of Greek libraries have created websites, which are freely accessible to users, mainly as regards the OPAC. The existence of the web version of the OPAC implies that libraries - generally speaking - have automated their services and catalogues.

Greek librarians feel that they have acquired experience from the continuous use of the Internet but they are self-educated. However, if they have the chance for further and continuing education through seminars, they are enthusiastic to attend. A driving force should be the Association of Greek Librarians and Information Scientists but they are also eager to get in-house training.

The Internet has not much affected library budgets, although libraries allocate money for accessing electronic resources. It is interesting to consider that the majority of Greek libraries have not cancelled their print journal subscriptions in favour of electronic journals. Nevertheless, the member libraries of the Hellenic Academic Libraries Link consortium have cancelled the print subscriptions, which are available electronically. The consortium keeps a print copy as a depository collection.

\section{Conclusions}

This self-funded study was undertaken to try and uncover the extent of Internet use in different types of libraries in Greece for the first time. From the study we can conclude that Greek libraries, especially the academic ones, keep up with current developments in information technology. Public and some municipal libraries follow suit. Special libraries are also keeping abreast with technologies but at a lower scale. School libraries remain in a growing phase. The knowledge acquired from this study can contribute to the further investigation of the attitude of Greek librarians towards IT innovations. Further searches could be conducted that explore and measure user satisfaction and the availability of digital content since the introduction of the Internet.

It is clear that this study has limitations. Among them we can observe the small size of the sample, although the population represents one library per respondent. A limitation is the small number of indicators studied and the combination of multiple variables in order to get results. It is recommended that a future study could include a larger sample and the analysis could be made more effective by using a statistical program (e.g. SPSS: Statistical Package of Social Sciences). The findings of future studies could be used in comparison with the data of the present study. Given those limitations we could regard this study as the first step towards measuring the Internet use and penetration in Greek libraries.

\section{References}

Annual measurement of the eEurope and i2010 indicators, conducted by the Observatory for the Greek Information Society (Apr. 2007), available at http://www.observatory.gr/page/default.asp?la=2\&id=16\&pl=424\&pk=45\&ap=423, visited on 3-92007.

CALIMERA Country report: Greece: information on public libraries, local museums and archives (2003), European Commission, IST Programme, available at http://www.calimera.org/Countries/Greece.aspx, visited on 3-9-2007.

Digital strategy 2006-2013 (2007), by Information Society, the Official Greek portal for I.S., available at http://www.infosoc.gr/infosoc/en-UK/sthnellada/committee/default1/top.htm, visited on 3-9-2007.

Doellgast, B. (2003), "Bibliotheken in Griechenland heute", Bibliotheksdienst, Vol 37 No 3, pp. 286-295.

Eurostat, "The digital divide in Europe", (2005), Statistics in Focus. Industry, trade and services, No 38, pp. 1-7.

Eurostat, "How skilled are Europeans in using computers and the Internet" (2006), Statistics in focus. Industry, trade and services, No 17, pp. 1-7.

Eurostat, "Internet activities in the European Union" (2005), Statistics in focus. Industry, trade and services, No 40, pp. 1-7.

Eurostat, "The Internet and other computer networks and their use by European enterprises to do eBusiness" (2006), Statistics in focus. Industry, trade and services, No 28, pp. 1-7.

Eurostat, "Use of the Internet among individuals and enterprises" (2006), Statistics in focus. Industry, trade and services, No 12, pp. 1-7.

Eurostat yearbook 2006-2007 (2007), Eurostat, Luxembourg. 
Fifth Six-Month Report of the Observatory for the Greek Information Society regarding broadband development in Greece (Jul. 2007), by the Observatory for the Greek Information Society, available at http://www.observatory.gr/page/default.asp?la=1\&id=183\&pl=110\&pk=398\&ap=101, visited on 39-2007 (currently available in Greek).

Internet World Stats, Internet usage statistics, available at http://www.internetworldstats.com/stats.htm, visited on 17-9-2007.

National Statistical Service of Greece, NSSG (2007), Hellas in Figures, available at http://www.statistics.gr/gr tables/hellas in numbers.pdf, visited on 21-11-2007 (in Greek).

National Strategic Reference Framework 2007-2013 (2007), by the Hellenic Ministry of Economy and Finance, available at http://www.mnec.gr/en/economics/National Strategic Reference Framework for 2007-13, visited on 3-9-2007.

OECD Communications outlook (2007a), Organisation for Economic Co-operation and Development, Paris.

OECD Fact book 2007: economic, environmental and social statistics (2007b), Organisation for Economic Co-operation and Development, Paris.

OECD Information technology outlook (2006), Organisation for Economic Co-operation and Development, Paris.

OECD Science, technology and industry scoreboard (2005), Organisation for Economic Co-operation and Development, Paris.

Papazoglou, A. and Semertzaki, E. (2001), "Changes and developments in Greek libraries", The Electronic Library, Vol 19 No 3, pp. 158-167.

Profile of Greek Internet users (2007), conducted by the Observatory for the Greek Information Society, available at http://www.observatory.gr/page/default.asp?la=2\&id=183\&pl=460\&pk=63\&ap=430, visited on 3-92007.

Profile of Greek Internet users (2005), conducted by the Observatory for the Greek Information Society, available at http://www.observatory.gr/page/default.asp?la=1\&id=22\&pl=110\&pk=255\&ap=101, visited on 17-92007 (in Greek).

Semertzaki, E. (2006), "History of libraries in Greece: a brief overview", Conference: Libraries: yesterday, today and tomorrow, Athens, 19 May, 2006, Eugenidion Foundation.

Strategic's telecoms, IT, Internet and new media observatory: Greece and Cyprus (2002), Strategic International Kataras S.A., Athens, $8^{\text {th }}$ ed.

Study for measuring the indicators of the eEurope and i2010 initiatives for the years 2006 and 2007: Report on the research findings among enterprises (Jan. 2007), prepared for the Greek Information Society Observatory, available at http://www.observatory.gr/page/default.asp?la=2\&id=183\&pl=460\&pk=59\&ap=430, visited on 19-92007.

Study for measuring the indicators of the eEurope and i2010 initiatives for the years 2006 and 2007: Report on the research findings among private individuals - households (Jan. 2007), prepared for the Greek Information Society Observatory, available at http://www.observatory.gr/page/default.asp?la=2\&id=183\&pl=460\&pk=58\&ap=430, visited on 19-92007.

Xenidou-Dervou, C. (2001), "Consortia journal licensing: experiences of Greek academic libraries", Interlending \& Document Supply, Vol. 29 No. 3, pp. 120-125.

\section{Further reading}

Benchmarking in a policy perspective. Report No. 2: Broadband Internet: final draft, 13 June 2006 (2006), Empirica, Bonn, available at http://ec.europa.eu/information society/eeurope/i2010/docs/studies/wp1 report broadband final dr aft june2006.doc, visited on 23-9-2007.

Broadband coverage in Europe: final report, 2006 survey, Data as of 31 Dec. 2005 (Nov. 2006), European Communities DG Information Society, available at http://ec.europa.eu/information society/eeurope/i2010/benchmarking/broadband coverage $06 \quad 200$ 6.doc, visited on 23-9-2007.

Information and Communication Technologies Survey (2004), conducted by the General Secretariat of National Statistical Service of Greece, available at http://www.statistics.gr/gr tables/S803 SFA 3 ICTSurvey 03.pdf, visited on 3-9-2007 (in Greek). 
Information Society benchmarking report (2005), available at

http://ec.europa.eu/information society/eeurope/i2010/docs/benchmarking/051222\%20Final\%20Ben chmarking\%20Report.pdf, visited on 19-9-2007.

John, Y.J. and Gorman, G.E. (2002), "Internet use in South Korea", Online Information Review, Vol 26 No 5, pp. 335-344.

Lu, W. and Du, J. and Zhang, J. and Ma, F. and Le, T. (2002), "Internet development in China", Journal of Information Science, Vol 28 No 3, pp. 207-223.

Mutula, S.M. (2002), "Current developments in the Internet industry in Botswana", The Electronic Library, Vol 20 No 6, pp. 504-511.

Xanthidis, D. and Nicholas, D. (2004), "Evaluating Internet usage and ecommerce growth in Greece", Aslib Proceedings, Vol 56 No 6, pp. 356-366.

Younis, A.R.M. (2002), "The perception and administrative effect of Internet usage in Jordanian university libraries", Online Information Review, Vol 26 No 3, pp.193-208.

\section{Websites}

[1] National Library of Greece, http://www.nlg.gr

[2]Technological Educational Institute (TEI) of Athens. Department of Library and Information Systems, http://www.teiath.gr/sdo/SDO.htm

[3] Technological Educational Institute (TEI) of Thessaloniki. Department of Library and Information

Systems, http://www.teithe.gr/cgi-bin/stbibliothikonomias.cgi

[4] Ionian University, http://www.ionio.gr

[5] Academy of Athens, http://www.academyofathens.gr

[6] National Documentation Centre, http://www.ekt.gr

[7] National Book Centre, http://www.ekebi.gr

[8] Greek Ministry of National Education and Religious Affairs, http://www.ypepth.gr

[9] Hellenic Academic Libraries Link, http://www.heal-link.gr

[10] Infolibraries, http://www.infolibraries.gr

[11] Veria Central Public Library, http://www.libver.gr

[12] Livadia Public Library, http://vivl-livad.voi.sch.gr

[13] Greek School Network, http://www.sch.gr

[14] Eugenidion Foundation, http://www.eugenfound.edu.gr

[15] Association of Greek Librarians and Information Scientists, http://www.eebep.gr

[16] Organising Committee for the Support of Libraries, http://www.goethe.de/synergasia

[17] Synergasia, a quarterly electronic library journal by the Organising Committee for the Support of Libraries, http://www.goethe.de/synergasia-periodiko

[18] Internet World Statistics: Usage and Population Statistics, http://www.internetworldstats.com/stats.htm

[19] Observatory for the Greek Information Society, http://www.observatory.gr

[20] Information Society: the official Greek portal for Information Society, http://www.infosoc.gr and Operational Program "Information Society" of the $3^{\text {rd }}$ Community Support Framework,

http://www.infosoc.gr/infosoc/en-UK/sthnellada, visited on 27-8-2007

\section{Acknowledgement}

The author would like to give special thanks to Mr. Panagiotis Shizas, Librarian at the National Documentation Centre for his assistance to distribute the questionnaire to Greek librarians via his mailing list. The author would also like to give sincere thanks to all respondents of the survey. 


\author{
About the author \\ Eva Semertzaki \\ Librarian, MSc. \\ Bank of Greece \\ Economic Research Department \\ Library Section \\ 21, E. Venizelos Ave. \\ 10250 Athens \\ Greece \\ tel.: +30-210-3202446 \\ fax: +30-210-3202129 \\ esemertzaki@bankofgreece.gr
}

Eva Semertzaki received her Bachelor degree in Ancient Greek Literature at the University of Crete, Rethymno, Greece and her MSc. in Library and Information Science at Simmons College, Boston, MA, upon winning a Fulbright scholarship. She is currently a librarian at the Bank of Greece in Athens. She has written articles in library journals (Modern Library journal in Greek, The Electronic Library and Information Outlook). She has translated in Greek guidelines for the European programmes PULMAN and CALIMERA and the IFLA guidelines on preservation of library material, as well as standards and guidelines by the American Library Association (ALA/ACRL). She has delivered papers in Greek conferences and was a lecturer at a seminar in Cambridge. She is currently the editor of the online library journal, Synergasia (means Co-operation), published in Greek by the Organising Committee for the Support of Libraries. Eva can be contacted at: 